детьми, способен к работе с ребенком, имеющим ограниченные возможности здоровья. (7)

$$
* * *
$$

1. Выготский Л.С. Собрание сочинений в шести томах: том 5. Основы дефектологии/ Л.С. Выготский М.: Книга по требованию, 2012. - 368 с.

2. Выготский Л.С. «Проблема культурного развития ребенка» //Вестник МГУ. Серия 14. Психология. 1991. №4. - C.5-18.

3. Клепцова Е.Ю. Психология и педагогика толерантности: учебн.пособие / Е.Ю. Клепцова. - М.: Академ.проект, 2004. - 176c.

4. Макоедова Г.В., Т.А. Савченко Социализация детей с ограничеснными возможностями здоровья: учебн. пособие / Г.В. Макоедова, Т.А. Савченко. - Магадан: СВГУ, 2013.-221с.

5. Назарова Н. Интегрированное (инклюзивное) образование: генезис и проблемы внедрения / Н. Назарова // Социальная педагогика. - 2010. - №1.

6. Наумов А.А. Интегрированное и инклюзивное обучение в образовательном учреждении. Инновационный опыт/ А.А. Наумоы, В.Р. Соколова, А.Н. Седегова - Волгоград: Учитель, 2012.

7. Яковлева И.М. Подготовка педагогов к реализации инклюзивного образования // Инклюзивное образование: методология, практика, технологии.

\title{
Киселева Е.В. \\ Формирование основных движений младших дошкольников через организацию подвижных игр
}

Самарский сочиильно-педагогический колледж (Россия, Самара)

doi: $10.18411 / s r-10-08-2017-03$

idsp: 000001:sr-10-08-2017-03

\section{Аннотация}

В данной статье рассматривается проблема формирования основных движений младших дошкольников. Соблюдение методики руководства педагогом при регулярном проведении подвижных игр, способствует лучшему выполнению основных движений младших дошкольников.

Ключевые слова: дошкольники, основные движения, младший дошкольный возраст, методика проведения подвижных игр.

По исследованиям НИИ гигиены и профилактики заболеваний, состояния здоровья и физического развития детей дошкольного возраста известно, что функциональные возможности детей младшего дошкольного возраста не реализуются на должном уровне в процессе разных видов занятий по физической культуре. Кроме того, двигательная активность дошкольников за время пребывания их в детском саду составляет 50\% периода бодрствования, что не позволяет полностью обеспечить биологической потребностью ребенка в движении. Это заставляет педагогов искать пути оптимизации движений за счёт проведения подвижных игр.

Следуя актуальности проблемы, было проведено исследование: «Формирование основных движений младших дошкольников через организацию подвижных игр».

Цель-изучить влияние подвижных игр на совершенствование основных движений детей младшего дошкольного возраста.

Задачи исследования:

1. Изучить техническую характеристику и методику формирования упражнений в лазании у дошкольников.

2. Раскрыть методику организации и проведения подвижных игр с дошкольниками.

3. Исследовать влияние подвижных игр на совершенствование основных движений младших дошкольников. 
Была выдвинута гипотеза, что проведение подвижных игр будет способствовать совершенствованию основных движений младших дошкольников, если:

- движения будут предварительно разучены на физкультурных занятиях;

- методика проведения подвижных игр будет учитывать психические и физиологические особенности детей 3-4 лет.

Изучив рекомендации Алямовской, Глазыриной Л.Д, Степаненковой Э.Я., Лайзане С.Я., Овсянкина В.А., Кенеман А.В., Хухлаевой Д.В. и др., мы приступили к проведению исследовательской деятельности.

Исследование проходило на базе второй младшей группы МБДОУ «Детский сад № 455», Кировского района г. о. Самара. Были выбраны 2 группы детей 3-4 лет экспериментальная и контрольная (по 10человек)

Сроки: с сентября 2016г. по апрель 2017 года.

Определена цель - сравнить уровень выполнения подлезания детьми четвёртого года жизни на физкультурном занятии и в подвижной игре.

Задачи:

1. Подобрать диагностические методики обследования основных движений детей младшего дошкольного возраста и провести диагностику

2. Освоить методику проведения подвижных игр с детьми младшего дошкольного возраста, ориентированную на этапы развития подвижной игры и особенности реакции детей 3-4 лет.

3. Организовать проведение подвижных игр с постепенным усложнением выполнения основного движения

4. Проанализировать результаты педагогической деятельности эксперимента.

На основе целевых ориентиров предлагаемых программой «От рождения до школы» под ред. Вераксы Н.Е (2015г) и методики обучения выполнения упражнений в подлезании (Хухлаева Д.В., Степаненкова Э.Я.) был проведён констатирующий эксперимент. Мы начали с диагностики упражнения в подлезании под шнур, подвешенный на высоте 50см. (способом «головой вперед»), выполняемого детьми на физкультурном занятии.

Цель: выявление умения детей подлезать под шнур, подвешенный на высоте 50 см., способом «головой вперед».

Выполнение: при подлезании способом «головой вперед» ребенок, наклонившись, сначала проносит голову, затем прогибаясь в спине, передвигает одну ногу, потом другую.

Для реализации задач эксперимента мы провели подвижную игру «Наседка и цыплята».В игре детям следовало выполнять подлезание под высоту 50 см. и тем же способом. Дети экспериментальной и контрольной групп продемонстрировали лучший уровень выполнение подлезания в подвижной игре. На этом основании был разработан перспективный план формирующего эксперимента для детей экспериментальной группы, основанный на проведении подвижных игр с усложнением выполнения подлезания.

Перспективный план совершенствования упражнений в подлезаниис февраля по март 2017г. при проведении подвижных игр с детьми экспериментальной группыМБДОУ «Детский сад № 455г.о.Самара

\begin{tabular}{|c|c|c|}
\hline $\begin{array}{c}\text { Месяц, № } \\
\text { недели }\end{array}$ & Игра & Задачи \\
\hline $\begin{array}{c}\text { Февраль } \\
1 \text { неделя }\end{array}$ & $\begin{array}{c}\text { «Наседка и } \\
\text { цыплята» }\end{array}$ & $\begin{array}{c}\text { Задачи: Упражнять детей в подлезании под высоту 50 см., в беге } \\
\text { врассыпную, стайкой и по прямой; развивать реакцию на словесный } \\
\text { сигнал. }\end{array}$ \\
\hline $\begin{array}{c}\text { Февраль } \\
2 \text { неделя }\end{array}$ & «Кролики» & $\begin{array}{c}\text { Задачи: Упражнять детей в подлезании под высоту 50 см., в беге } \\
\text { врассыпную, стайкой и по прямой. Развивать умение выполнять } \\
\text { движения по сигналу. }\end{array}$ \\
\hline
\end{tabular}




\begin{tabular}{|c|c|c|}
\hline $\begin{array}{l}\text { Февраль } \\
3 \text { неделя }\end{array}$ & $\begin{array}{c}\text { «Мыши в } \\
\text { кладовой» }\end{array}$ & $\begin{array}{c}\text { Задачи: : Упражнять детей в подлезании под высоту } 50 \text { см., в беге } \\
\text { врассыпную, стайкой и по прямой. Развивать у детей умение выполнять } \\
\text { движения по сигналу. }\end{array}$ \\
\hline $\begin{array}{c}\text { Март } \\
1 \text { неделя }\end{array}$ & $\begin{array}{c}\text { «Наседка и } \\
\text { цыплята» }\end{array}$ & $\begin{array}{c}\text { Задачи: Упражнять детей в подлезании под высоту } 48 \text { см., в беге } \\
\text { врассыпную, стайкой и по прямой; развивать реакцию на словесный } \\
\text { сигнал. }\end{array}$ \\
\hline $\begin{array}{c}\text { Март } \\
2 \text { неделя }\end{array}$ & «Кролики» & $\begin{array}{l}\text { Задачи: Упражнять детей в подлезании под высоту } 48 \text { см., в беге } \\
\text { врассыпную, стайкой и по прямой. Развивать умение выполнять } \\
\text { движения по сигналу. }\end{array}$ \\
\hline $\begin{array}{c}\text { Март } \\
3 \text { неделя }\end{array}$ & $\begin{array}{c}\text { «Мыши в } \\
\text { кладовой» }\end{array}$ & $\begin{array}{c}\text { Задачи: : Упражнять детей в подлезании под высоту } 47 \text { см., в беге } \\
\text { врассыпную, стайкой и по прямой. Развивать у детей умение выполнять } \\
\text { движения по сигналу. }\end{array}$ \\
\hline $\begin{array}{c}\text { Март } \\
4 \text { неделя }\end{array}$ & $\begin{array}{l}\text { «Наседка и } \\
\text { цыплята» } \\
\text { «Кролики» }\end{array}$ & $\begin{array}{c}\text { Задачи: Упражнять детей в подлезании под высоту } 47 \text { см., в беге } \\
\text { врассыпную, стайкой и по прямой; развивать реакцию на словесный } \\
\text { сигнал. } \\
\text { Задачи: Упражнять детей в подлезании под высоту } 46 \text { см., в беге } \\
\text { врассыпную, стайкой и по прямой. Развивать умение выполнять } \\
\text { движения по сигналу. }\end{array}$ \\
\hline $\begin{array}{c}\text { Апрель } \\
1 \text { неделя }\end{array}$ & $\begin{array}{l}\text { «Мыши в } \\
\text { кладовой» } \\
\text { «Кролики» }\end{array}$ & $\begin{array}{c}\text { Задачи: : Упражнять детей в подлезании под высоту } 46 \text { см., в беге } \\
\text { врассыпную, стайкой и по прямой. Развивать у детей умение выполнять } \\
\text { движения по сигналу. } \\
\text { Задачи: Упражнять детей в подлезании под высоту } 45 \text { см., в беге } \\
\text { врассыпную, стайкой и по прямой. Развивать умение выполнять } \\
\text { движения по сигналу. }\end{array}$ \\
\hline $\begin{array}{c}\text { Апрель } \\
2 \text { неделя }\end{array}$ & $\begin{array}{c}\text { «Наседка и } \\
\text { цыплята» }\end{array}$ & $\begin{array}{c}\text { Задачи: Упражнять детей в подлезании под высоту } 45 \text { см., в беге } \\
\text { врассыпную, стайкой и по прямой; развивать реакцию на словесный } \\
\text { сигнал. } \\
\text { Задачи: : Упражнять детей в подлезании под высоту } 45 \text { см., в беге } \\
\text { врассыпную, стайкой и по прямой. Развивать у детей умение выполнять } \\
\text { движения по сигналу. }\end{array}$ \\
\hline
\end{tabular}

При проведении новых или малознакомых подвижных игр с детьми экспериментальной группы, была применена иная методика подачи сигнала на окончание игровых действий, т.к. в 3-4 года реакция внимания затруднена у малышей. Сигнал подавался в три этапа, например:

первый - уточнение изменения действий (большая птица);

второй - как необходимо отреагировать (убегайте);

третий - непосредственно звуковой сигнал (Кар-кар).

Кроме того игру организовывали таким образом, чтобы каждый малыш, независимо от физических возможностей, оказался в позиции выигрыша. Если на окончание игры ребёнок не реагировал (не прячется в свой домик), воспитатель в одну руку брал игрушку (Ворону), другой - руку малыша и, сохраняя дистанцию между игрушкой и ребёнком, заводил малыша в игровой домик. Сразу озвучивая похвалу: «Молодцы дети! Все убежали от Большой птицы!» Всё это способствовало увеличению интереса к выполнению основных движений в подвижных играх.

В контрольном эксперименте мы вновь провели обследование детей обеих групп, применив методику констатирующего эксперимента.

Анализ данныхполученных в контрольном эксперименте показывает, что в процессе игры дети экспериментальной группы стали заметно увереннее выполнять упражнение, движения выполнялись последовательно, повысилась активность и старательность выполнения основных движений.

Результаты приведены в сравнительной диаграмме контрольного эксперимента по результатам обследования подлезаниядетей в подвижной игре (рис.1).Показатели подлезания у детей экспериментальной группы оказались чуть лучше, чем у детей контрольной группы, но, всё же не имели большой разницы. Однако, дети экспериментальной группы проявляли не только желание участвовать в подвижных играх, но и просили поиграть в игры, которые были включены в их двигательную 
деятельность в формирующем эксперименте. Мы считаем, что эти игры были понятны по выполнению движений и образному содержанию, вызывали положительные эмоции, поэтому и вызывали больший интерес.

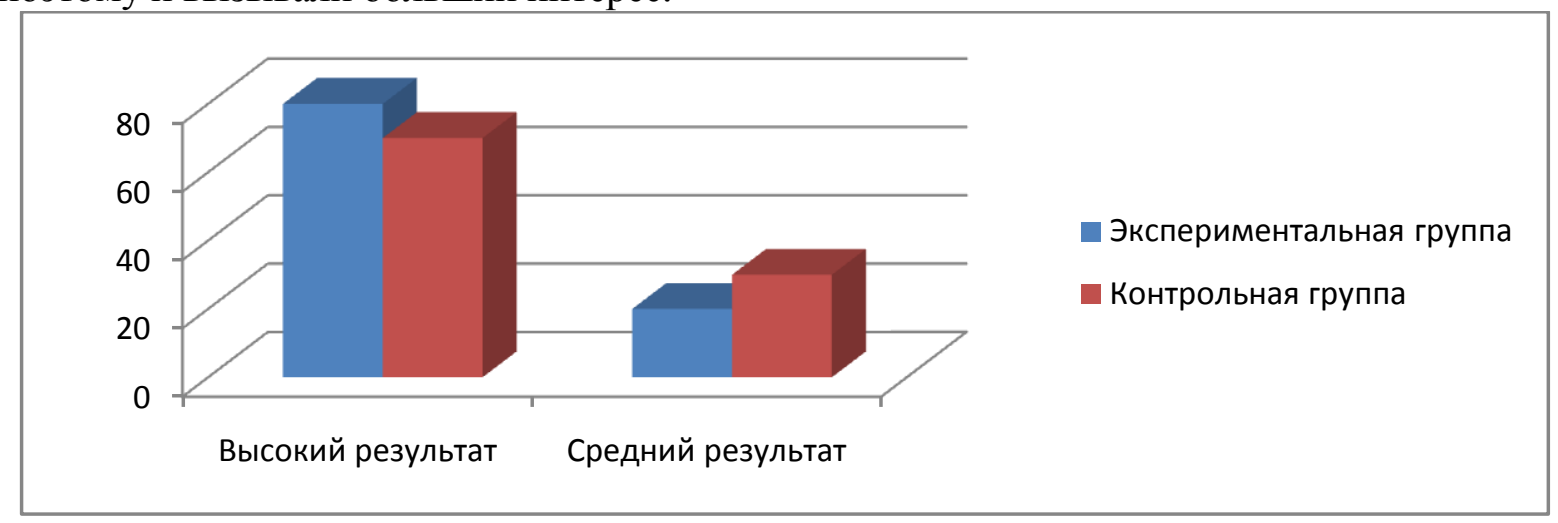

Рис.1 - Сравнительная диаграмма результатов обследования подлезания в подвижной игре детей экспериментальной и контрольной групп в контрольном эксперименте.

Из полученных данных мы делаем вывод, наши результаты подтвердили мнение физиологов и педагогов, в том числе Степаненковой Э.Я., что в младшем дошкольном возрасте активно участвуют в движении только крупные группы мышц, поэтому у малышей не будет проявляться существенной разницы качества выполнения основных движений.

Неоспоримо, что выполнение детьми этих движений в подвижной игре идёт с большим интересом и желанием: высокий уровень мотивации - сама подвижная игра с её атрибутами, точное пояснение педагога во время выполнения основного движения детьми, учёт возрастных особенностей при подаче сигнала на окончание игровых действий обеспечивает более качественное выполнения основного движения.

Важно, как можно чаще, упражнять малышей в выполнении основных движений и делать это нужно применяя подвижные игры, доступные детям.

Таким образом, проведение подвижных игр, является эффективным средством совершенствования основных движений детей младшего дошкольного возраста.

Наша гипотеза нашла свое подтверждение: действительно, проведение подвижных игр, способствовало лучшему выполнению основных движений младших дошкольников, Т.К.:

- движения были предварительно разучены на физкультурных занятиях;

- методика проведения подвижных игр учитывала психические и физиологические особенности детей 3-4 лет, что заключалось в пояснении этапов выполнения движений и подаче сигнала на окончание игровых действия в три этапа.

Рекомендации педагогам ДОУ по применению методики проведения подвижные игр с детьми младшего дошкольного возраста, способствующей развитию основных движений.

1. При выборе подвижных игр ориентироваться на образовательную программу «От рождения до школы», под редакцией Н.Е. Вераксы, Т.С. Комаровой, М.А.Васильевой.

2. Во время проведения игры пояснять для детей все фазы выполнения основного движения.

3. Для методически правильного проведения подвижных игр, учитывать психологические особенности младших дошкольников:

- проводить игровые действия,без предварительного объяснения содержания игры; 
- сигнал на окончание игровых действия организовывать в три этапа.

4. По мере накопления детьми двигательного опыта усложнять само основное движение в соответствии с возрастными возможностями детей.

$* * *$

1. Железняк, Ю.Д. Основы научно-методической деятельности в физической культуре и спорте: учеб.пособие для студ. Высш. Учеб. Заведений / Ю.Д. Железняк, П.К. Петров. - 3-е изд., испр. - М., 2007. $-73 \mathrm{c}$.

2. Программа «От рождения до школы», под ред.Н.Е. Вераксы, Т.С. Комаровой, М.А.Васильевой - М.: Мозаика-Синтез, 2015

3. Шишкина, В. А., Дедулевич М. Н. Двигательное развитие дошкольника. Редактор: Шумак С. Е. Издательство: Белый ветер, 2014 г.- 136 с. 